\title{
Analysis of Defense Genes Expression in Maize upon Infection with Peronosclerospora sorghi
}

\author{
Y. SiREESHA* and R. VelazhaHAN* \\ Department of Plant Pathology, Centre for Plant Protection Studies, Tamil Nadu Agricultural University, \\ Coimbatore-641003, Tamil Nadu, India
}

(Received 17 June 2016; Accepted 4 October 2016)

\begin{abstract}
Downy mildew, caused by Peronosclerospora sorghi is one of the important diseases affecting maize (Zea mays L.) production worldwide. Several downy mildew resistant maize lines have been identified. However, variability in the degree of resistance among maize genotypes to $P$. sorghi has been reported. In the present study the molecular basis of resistance of maize to $P$. sorghi was studied by using differential-display reverse transcription PCR (DDRT-PCR) technique. Maize seedlings of downy mildew resistant (MAI 756) and susceptible (CM 500) cultivars at two-leaf stage were inoculated with P. sorghi and leaf samples were collected at 0,3 and 5 days after inoculation and analyzed for differentially expressed cDNAs using cDNA-RAPD approach. A total of 17 cDNA fragments corresponding to transcripts that showed alterations during the defence response of maize to $P$. sorghi were identified. Genes involved in signal transduction and several genes with unknown functions were found to be upregulated in maize after infection by P. sorghi. Among 35 random primers tested, OPD-05 has identified a differentially expressed cDNA coding for serine/threonine kinase protein in resistant maize genotype. Constitutive and high level expression of serine/threonine kinase gene was observed in the uninoculated plants of resistant genotype, whereas no expression of this gene was observed in uninoculated plants of susceptible genotype. However, the transcript level was induced 3 days after inoculation in the susceptible genotype and slightly reduced 5 days after inoculation. This study represents the first identification of maize serine/threonine kinase gene that is upregulated following infection by $P$. sorghi.
\end{abstract}

Keywords: Zea mays, Peronosclerospora sorghi, downy mildew, transcriptomics, differential display RT-PCR

\section{Introduction}

Downy mildew of maize (Zea mays L.) caused by the obligate oomycete Peronosclerospora sorghi (Weston \& Uppal) C. G. Shaw has become an increasingly important problem affecting maize production in sub-tropical and tropical regions of Asia (Rashid et al. 2013). Several downy mildew resistant maize lines have been identified for use in resistance breeding programs (Yen et al. 2004; Rashid et al. 2013). Variability in different maize cultivars with respect to the level of resistance to $P$. sorghi has been described

\footnotetext{
*Corresponding authors; E-mails: velazhahan@hotmail.com; sireesha.yeturi@gmail.com
} 
(George et al. 2004), but the mechanism of resistance remains elusive. Disease resistance and susceptibility of plants are governed by the combination of the host genotype and the pathogen and depend on a complex exchange of signals and responses between them. During the process of host-pathogen co-evolution, plants have developed various strategies to perceive pathogen infection and translate the perception into effective defense responses to protect against pathogen attack (Jones and Dangl 2006). Some of the defense mechanisms of plants are constitutive (pre-formed) and provide physical and chemical barriers to impede pathogen infection; others are induced only after infection by pathogens. The pre-existing defense molecules, called "phytoanticipins", include phenolics, phenolic glycosides, unsaturated lactones, saponins, cyanogenic glycosides, glucosinolates, 5-alkylated resorcinols and dienes (Osbourn 1996). Induced plant defense responses involve a complex network of signal transduction and rapid activation of expression of various defense genes following pathogen infection (Yang et al. 1997). Plant cell walls can be reinforced by lignifications, accumulation of callose and hydroxyprolinerich glycoproteins (HRGPs) (Showalter 1993). Hypersensitive cell death is triggered to prevent spread of the pathogen (Mittler and Lam 1995). Several antimicrobial compounds such as phytoalexins (Dixon 1986) and pathogenesis-related proteins (Linthorst 1991) are then produced to restrict pathogen growth.

A key difference between resistant and susceptible plants is the timely recognition of the invading pathogen and rapid activation of host defense mechanisms. A resistant plant is capable of deploying a wide variety of defense responses rapidly to prevent pathogen colonization. In contrast, a susceptible plant exhibits much weaker and slower responses that fail to restrict pathogen growth and/or spread. As a result, a susceptible plant is often severely affected or even killed by pathogen infection. The activation of defense responses in plants is initiated by recognition of pathogen-derived molecules termed pathogenassociated molecular patterns (PAMPs) by receptor proteins called pattern recognition receptors (PRRs) in the plant (Boller and Felix 2009). The interaction of PAMPs with host PRRs leads to signal transduction and activation of a range of defence mechanisms (Dodds and Rathjen 2010). A number of disease resistance genes from plants that confer resistance to diverse pathogens, such as fungi ( $C f-9, C f-2, L, M, I_{2}$ and $\left.R p p 5\right)$, bacteria (Pto, RPS2, RPM1 and Xa21) and virus $(N)$ have been characterised (Gururani et al. 2012). Interestingly, the products of these resistance genes share structural similarities, even though these genes confer resistance to diverse pathogens. This finding suggests that the resistance genes function in common signalling pathways leading to defense against pathogen invasion.

Understanding the resistance mechanisms involved in plant-pathogen interactions can help in the development of new pathogen-resistant crop cultivars. The recent developments of microarray-based expression profiling methods, together with the availability of genomic and/or ESTs (expressed sequence tags) sequence data for some plant species has allowed significant progress in the characterization of plant pathogenesis-related responses (Al-Taweel and Fernando 2011). Interaction transcriptome studies are widely used to understand the responses of both the pathogen and the host during the infection process (Birch and Kamoun 2000; Wise et al. 2007; Mosquera et al. 2009; Kim et al. 2010). Sev- 
eral methods of transcript profiling such as DNA microarray (Clarke and Zhu 2006), differential hybridization, subtractive hybridization, differential display (DD) RT-PCR (Liang and Pardee 1992), serial analysis of gene expression(SAGE) (Velculescu et al. 1995), Massive Parallel Signature Sequencing (Brenner et al. 2000), Gene Calling (Shimkets et al. 1999), RNA-Seq (Wang et al. 2009), cDNA-amplified fragment polymorphism (cDNA-AFLP) (Bachem et al. 1996) and cDNA-RAPD (Lovejot et al. 2015) are widely used to study plant-pathogen interactions (Donson et al. 2002). DDRT-PCR, cDNA-AFLP and cDNA-RAPD are gel-based transcript profiling systems based on electrophoretic fingerprinting of amplified cDNA fragments (Liang 2002). The DDRT-PCR technique which allows identification and isolation of eukaryotic cDNAs expressed differentially under various conditions has been successfully exploited to analyse many plant-pathogen interactions, such as potato-Phytophthora infestans (Collinge and Boller 2001), pepper-Phytophthora capsici (Munoz and Bailey 1998), olive-Spilocaea oleagina (Benitez et al. 2005), wheat-Tilletia indica (Tripathi et al. 2013), periwinkle (Catharanthus roseus)mollicutes, viz. Spiroplasma citri, Candidatus Phytoplasma aurantifolia and stolbur phytoplasma (Jagoueix-Eveillard et al. 2001), soybean-Pseudomonas syringae pv. glycinea (Seehaus and Tenhaken 1998), Vigna radiata and Vigna umbellate-Mungbean yellow mosaic virus (Lovejot et al. 2015). To improve the understanding of defence responses, the molecular response of susceptible (CM-500) and resistant (MAI-756) maize genotypes after inoculation with $P$. sorghi was studied by DDRT-PCR using cDNA- RAPD approach.

\section{Materials and Methods}

\section{Greenhouse studies}

Seeds of downy mildew susceptible (CM 500) and resistant (MAI 756) maize genotypes obtained from the Indian Institute of Maize Research, New Delhi, were sown in $30 \mathrm{~cm}$ diameter pots filled with sterilized maize field soil (clay loam with a $\mathrm{pH}$ of 7.5) at the rate of 5 seeds per pot and the plants were grown in a growth chamber maintained at $18-20^{\circ} \mathrm{C}$ temperature and $>90 \%$ relative humidity.

For the preparation of inoculum of $P$. sorghi, maize leaves (CM 500) showing symptoms of downy mildew were collected from the experimental farms of Tamil Nadu Agricultural University, Coimbatore, India and cut into 4-5 cm lengths and placed with their abaxial side facing up in $9 \mathrm{~cm}$ diameter Petri dishes lined with wet filter paper on both the sides. The plates were incubated in the dark for $6-7 \mathrm{~h}$ at $20^{\circ} \mathrm{C}$ for sporulation (Narayana et al. 1995). Conidia were harvested from the surface of leaves by gently washing them into cold distilled water using a camel hair brush. The concentration of conidia was adjusted to $1 \times 10^{8}$ conidia $\mathrm{ml}^{-1}$. The wetting agent, Tween $20(0.02 \%)$ was mixed with the conidial suspension before inoculation. The seedlings at two-leaf stage were spray inoculated with conidial suspension using a hand-held sprayer until run-off (Sireesha et al. 2015). The inoculated plants were incubated in a growth chamber at $20{ }^{\circ} \mathrm{C}$ and $>90 \% \mathrm{RH}$. Uninoculated control plants were maintained separately under the same growing conditions. 


\section{Sampling}

Leaves of 3 individual plants were collected from the susceptible and resistant plants at 0 , 3 and 5 days after inoculation, frozen immediately in liquid nitrogen and stored at $-70{ }^{\circ} \mathrm{C}$ until RNA isolation.

\section{RNA isolation}

Total RNA was isolated from leaves of susceptible and resistant plants using Plant Total RNA kit according to the supplier's instructions (Sigma Aldrich, Co., St. Louis, USA) followed by a DNase (Invitrogen, San Diego, CA, USA) treatment to degrade residual genomic DNA. All solutions used were treated with diethyl pyrocarbonate (DEPC, Sigma Aldrich). RNA integrity was checked by gel electrophoresis on a $0.8 \%$ denaturing agarose gel (Sambrook et al. 2001) and quantified using NanoDrop ND-3300 Fluorospectrometer (NanoDrop products, Thermo Scientific, Wilmington, DE, USA) at $260 \mathrm{~nm}$.

\section{First-strand cDNA synthesis}

Two $\mu \mathrm{g}$ of total RNA from each sample was used as the template for First-strand cDNA synthesis using RevertAid First Strand cDNA Synthesis Kit (Thermo Scientific, Wilmington, DE, USA) according to the manufacturer's instructions.

\section{Differential display RT-PCR (DDRT-PCR)}

The single strand cDNA was used as template for PCR using 35 random decamer primers (Operon, Cologne, Germany) (Table S1*). The reaction mixture contained $10 \mu \mathrm{l}$ of $2 \mathrm{X}$ PCR Master mix (Smart prime, USA), $1 \mu$ of the diluted (1:10) cDNA synthesis reaction and $2 \mu \mathrm{l}$ of 10 -mer oligonucleotide primer $(10 \mathrm{pmol} / \mu \mathrm{l})$ in $20 \mu \mathrm{l}$ final volume. Amplifications were performed in an Eppendorf Master Cycler ep-gradient S (Eppendorf, AG, Hamburg, Germany) with the following thermal cycle profile: initial denaturation for 5 min at $94{ }^{\circ} \mathrm{C}$, followed by 40 cycles of denaturation at $94{ }^{\circ} \mathrm{C}$ for $1 \mathrm{~min}$, annealing at $42{ }^{\circ} \mathrm{C}$ for $1 \mathrm{~min}$, extension at $72{ }^{\circ} \mathrm{C}$ for $1 \mathrm{~min}$, and final extension at $72{ }^{\circ} \mathrm{C}$ for $10 \mathrm{~min}$. The PCRamplified products were separated on $1.5 \%$ agarose gel containing $0.5 \mu \mathrm{g} / \mathrm{ml}$ of ethidium bromide in Tris-acetate-EDTA (TAE) buffer (0.04 M Tris-acetate, $0.001 \mathrm{M}$ EDTA, pH 8.0). The PCR products were visualized under UV light and gel images were acquired with an Alpha Imager 2000 (Alpha Innotech, San Leandro, CA, USA). Differentially displayed DNA bands were excised and purified from the gel using the Genei Gel extraction kit (Genei, Merck specialities Pvt. Ltd., Mumbai) following the manufacturers' instructions. The DNA was cloned in the pGEM-T Easy Vector (Promega Corporation, Madison, WI, USA), following the manufacturer's instructions. The insert was sequenced from both ends by using forward and reverse primers (SP6 and T7). Sequencing was done at Chromous Biotech Pvt. Ltd., Bangalore, India. The experiment was repeated twice and PCR reactions were performed in duplicate.

*Further details about the Electronic Supplementary Material (ESM) can be found at the end of the article. 


\section{Sequence analysis}

The sequences were compared with those in the GenBank database using the BlastX program (Altschul et al. 1997) (http: //www. ncbi.nlm.nih.gov/blast).

\section{Results}

The PCR amplified bands obtained from the amplification of cDNA synthesized from the total RNA extracted from both resistant (MAI 756) and susceptible (CM 500) maize genotypes at 0,3 and 5 days after inoculation using 35 random 10-mer primers clearly indicated differences in the profiles of susceptible and resistant genotypes. Some of the bands, however, were unique to either susceptible or resistant genotypes. Seventeen differentially amplified PCR products were excised from the agarose gel, purified, cloned and sequenced. The nucleotide sequences of the cDNA clones were compared with those in GenBank database using BlastX search to reveal similarities (Table 1). Of the 17 differentially amplified cDNA fragments, one showed significant similarity (92\%) to serine/ threonine kinase protein and another one showed similarity (41\%) to LRR receptor-like serine/threonine-protein kinase, seven showed similarity to previously sequenced protein genes and eight showed no similarity to known sequences in the database. The sequence of the DNA band at $\sim 600$ bp (Fig. 1), which had been amplified by the primer OPD-05 (band h) from $P$. sorghi-infected resistant genotype, had strong homology ( $92 \%$ identity) with serine/threonine kinase from maize. A higher expression level of this gene was observed in uninoculated plants of the resistant genotype, indicative of constitutive expression; whereas no expression of this gene was observed in uninoculated plants of the susceptible genotype. However, the transcript level in the susceptible genotype was induced 3 days after inoculation with $P$. sorghi and slightly reduced 5 days after inoculation. The amplification profiles of differentially expressed transcripts obtained with primers OPC-

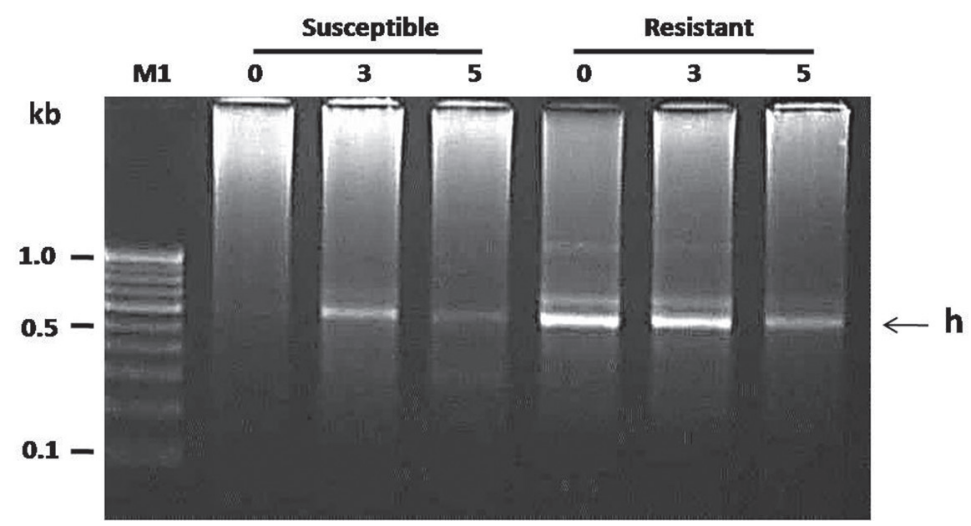

Figure 1. Amplification profile of differentially expressed transcripts obtained with primer OPD-05 in susceptible (CM 500) or resistant (MAI 756) maize genotypes inoculated with P. sorghi. Numbers indicate days after inoculation. Arrow shows a differentially expressed cDNA. Letter (h) indicates band ID as per Table 1 


\begin{tabular}{|c|c|c|c|c|c|c|c|c|}
\hline 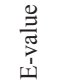 & $\begin{array}{l}\infty \\
\stackrel{\sim}{N} \\
\stackrel{N}{n}\end{array}$ & $\vec{F}$ & $\stackrel{\sim}{\dot{f}}$ & $\begin{array}{l}\stackrel{n}{\delta} \\
\ddot{n}\end{array}$ & $\begin{array}{l}n \\
0 \\
0 \\
\infty\end{array}$ & $\frac{a}{\tilde{j}}$ & $\begin{array}{l}\text { oे } \\
\text { d }\end{array}$ & $\hat{0}$ \\
\hline 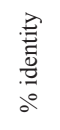 & 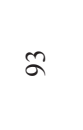 & む゙ & m & $\dot{m}$ & $F$ & 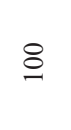 & $\stackrel{\infty}{\sim}$ & $\infty$ \\
\hline 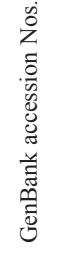 & 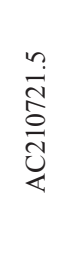 & 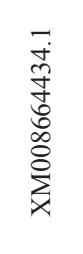 & 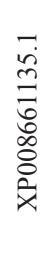 & 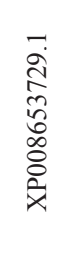 & 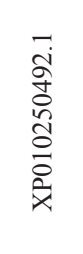 & 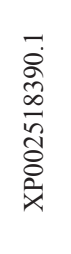 & 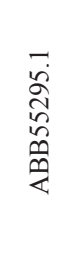 & 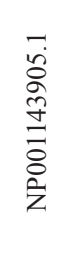 \\
\hline 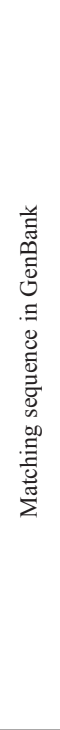 & 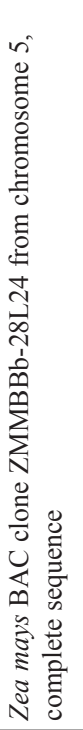 & 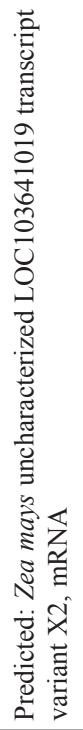 & 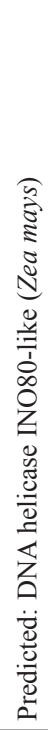 & 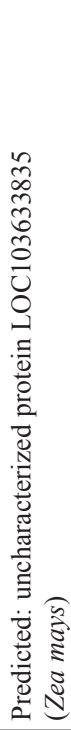 & 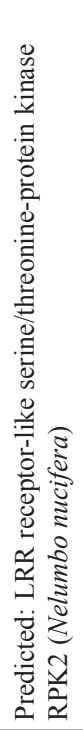 & 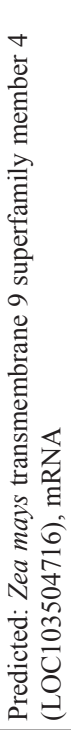 & 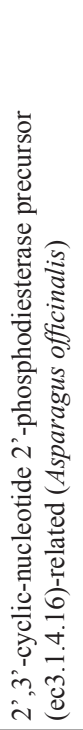 & 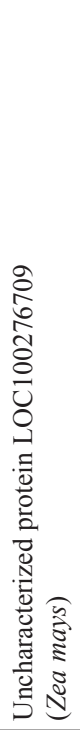 \\
\hline 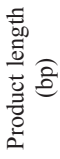 & $n$ & $\underset{m}{\infty}$ & $\hat{\mathrm{m}}$ & $\stackrel{\infty}{\stackrel{n}{\sigma}}$ & $\hat{\text { s }}$ & $\underset{\forall}{\forall}$ & $\hat{n}$ & ㄱ. \\
\hline 离 & $\begin{array}{l}\text { oे } \\
\text { 充 } \\
\text { ô }\end{array}$ & $\begin{array}{l}\overrightarrow{0} \\
\text { के } \\
\text { ô }\end{array}$ & $\begin{array}{l}n \\
1 \\
0 \\
0 \\
0\end{array}$ & $\begin{array}{l}\text { 足 } \\
\dot{1} \\
\tilde{0}\end{array}$ & 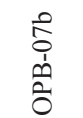 & $\begin{array}{l}\text { oे } \\
\text { ஸे } \\
\text { ô }\end{array}$ & $\begin{array}{l}n \\
0 \\
0 \\
0\end{array}$ & $\begin{array}{l}\text { oे } \\
\text { ல } \\
\text { ô }\end{array}$ \\
\hline$\underset{\mathscr{n}}{\vec{E}} \cong$ & 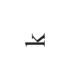 & $\sigma$ & 4 & 0 & $\tau$ & - & $\Xi$ & סמ \\
\hline
\end{tabular}

Cereal Research Communications 45, 2017 


\begin{tabular}{|c|c|c|c|c|c|c|c|c|c|}
\hline 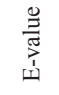 & $\vec{m}$ & $\stackrel{\stackrel{\sim}{i}}{i}$ & $\stackrel{0}{0}$ & $\stackrel{+}{+}$ & $\stackrel{\circ}{\infty}$ & $\stackrel{+}{n}$ & 1 & $\begin{array}{l}\tilde{D} \\
\stackrel{\sim}{\sim}\end{array}$ & $\begin{array}{l}\dot{0} \\
\vdots \\
\dot{q}\end{array}$ \\
\hline $\begin{array}{l}\stackrel{\vec{E}}{\vec{E}} \\
\stackrel{0}{0} \\
\stackrel{0}{\circ}\end{array}$ & $\stackrel{\infty}{n}$ & $\tilde{n}$ & $\alpha$ & Әे & in & 우 & 1 & $\stackrel{\circ}{\circ}$ & $m$ \\
\hline 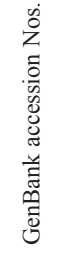 & 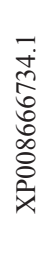 & 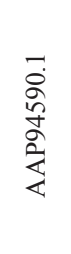 & 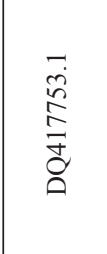 & 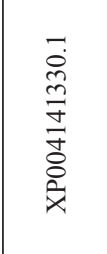 & $\begin{array}{l}\overrightarrow{0} \\
8 \\
0 \\
\infty \\
8 \\
0 \\
0 \\
0 \\
0\end{array}$ & 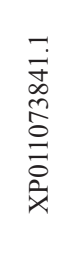 & 1 & $\begin{array}{l}- \\
\stackrel{\infty}{N} \\
\stackrel{N}{N}\end{array}$ & 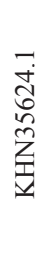 \\
\hline 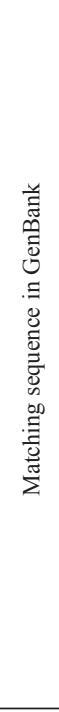 & 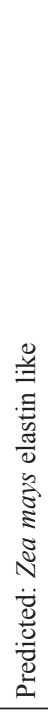 & 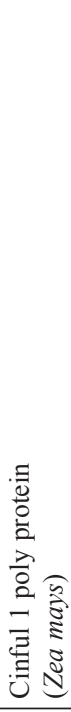 & 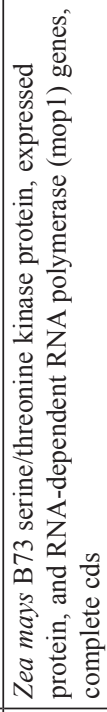 & 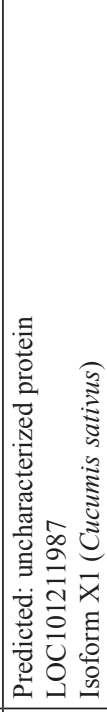 & 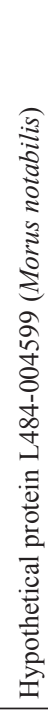 & 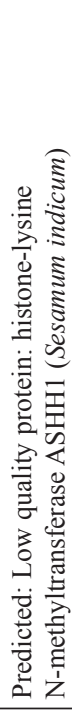 & 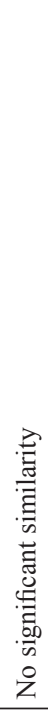 & 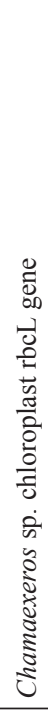 & 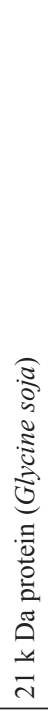 \\
\hline 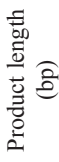 & ָి & $\stackrel{m}{\sigma}$ & $\overrightarrow{\widehat{\sigma}}$ & ñ & $\stackrel{\circ}{\sim}$ & $\stackrel{n}{=}$ & $\stackrel{\curvearrowright}{\curvearrowright}$ & ৯े & $\infty$ \\
\hline 壹 & $\begin{array}{l}\text { ồ } \\
\text { مे } \\
\text { ô }\end{array}$ & $\begin{array}{l}\text { ô } \\
\hat{1} \\
\text { Oे }\end{array}$ & $\begin{array}{l}\text { o } \\
1 \\
\text { مิ } \\
0\end{array}$ & 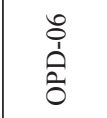 & $\begin{array}{l}\text { o } \\
\text { 1े } \\
\text { ô }\end{array}$ & $\begin{array}{l}\hat{0} \\
\hat{1} \\
\hat{0}\end{array}$ & $\begin{array}{l}\text { oे } \\
\text { ô } \\
\text { ô }\end{array}$ & $\begin{array}{l}n \\
0 \\
1 \\
1 \\
0\end{array}$ & $\frac{7}{\frac{1}{a}}$ \\
\hline $\overrightarrow{\mathbb{E}^{\prime}}$ & $=$ & م & 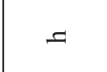 & $-r$ & $\cdot-$ & 0 & $\therefore$ & 0 & $\sigma$ \\
\hline
\end{tabular}


09, OPD-03 and OPD-06 are shown in Fig. S1. The basal level expression of some genes in the uninfected resistant genotype was higher than in the susceptible one, suggesting constitutive expression of defense responses.

\section{Discussion}

In plants receptor-like kinases (RLKs) play fundamental roles in perceiving external stimuli, activating downstream signalling pathways, and regulating cellular behaviour in response to pathogen infection. Most plant RLKs are composed of an extracellular domain, a transmembrane domain, and a cytoplasmically localized domain with serine/ threonine kinase activity. The extracellular domain is thought to function in recognition and binding of a specific ligand, the transmembrane domain to anchor the protein in a membrane, and the protein kinase domain to transduce the signal (Walker 1994; Hardie 1999). RLK proteins are known to be involved in plant-pathogen interactions and plant defense responses such as the rice bacterial blight resistance gene Xa21 (Song et al. 1995) and A. thaliana flagellin perception gene FLS2 (Gomez-Gomez and Boller 2000). Song et al. (1995) isolated the rice Xa21 gene, which confers resistance to Xanthomonas oryzae pv. oryzae race 6 , by positional cloning. The sequence of the predicted protein, which carries both a leucine-rich repeat motif and a serine-threonine kinase-like domain, suggests a role in cell surface recognition of a pathogen ligand and subsequent activation of an intracellular defense response. The discovery that the tomato Pto resistance gene encode serine/threonine protein kinases further suggests a central role for protein phosphorylation in signal perception and transduction in disease resistance (Martin et al. 1993).

In the present study, it was observed that the serine/threonine kinase gene was induced 3 days after inoculation with $P$. sorghi in the susceptible genotype. Similar induced expression of $\mathrm{R}$ gene has been reported by Yoshimura et al. (1998). The authors reported that $\mathrm{Xal}$ gene in rice which confers resistance to Japanese race 1 of Xanthomonas oryzae pv. oryzae, the causal pathogen of bacterial blight (BB) was induced upon inoculation with the bacterial pathogen and wounding. Yang et al. (2013) reported that a wheat cysteine-rich receptor kinase (CRK) gene, TaCRK1, isolated from Rhizoctonia cerealisresistant wheat CI12633 was highly expressed in resistant (CI12633) than in susceptible (Wenmai 6) genotype after $R$. cerealis infection and exogenous abscisic acid (ABA) treatment. Narsai et al. (2013) demonstrated that inoculation of rice with $X$. oryzae pv. oryzae, caused significant induction of several signalling components, membrane bound receptor kinases and specific WRKY and NAC transcription factors within $24 \mathrm{~h}$ of inoculation. For the first time, we have shown that serine/threonine kinase gene was constitutively expressed in resistant maize genotype and activated in susceptible genotype upon infection by P. sorghi. The expression of serine/threonine kinase gene may be involved in enhancement of resistance against the pathogen.

Furthermore, in the present study it was observed that the transcript level was slightly reduced 5 days after inoculation in the susceptible genotype. In general, plant cell reprogramming has been observed in several pathosystems, including maize-Ustilago maydis, rice-Magnaporthe oryzae and Medicago truncatula-Colletotrichum trifolii (Torregrosa et 
al. 2004; Doehlemann et al. 2008; Marcel et al. 2010). Studies of biotrophic pathogens have shown that they actively suppress plant defenses after an initial microbe-associated molecular pattern-triggered activation (Caldo et al. 2006; Doehlemann et al. 2008). For example, transcriptional profiling of maize genes during infection by a biotrophic basidiomycete, viz. U. maydis revealed a transient induction of pathogenesis-related genes (PR genes), chitinases, and glucanases at $12 \mathrm{~h}$ after infection that were repressed $24 \mathrm{~h}$ after the infection began (Doehlemann et al. 2008). Similar patterns of plant defense gene induction, followed by suppression, have been observed in other biotrophic pathosystems (Caldo et al. 2006; Doehlemann et al. 2008) and the hemibiotrophic Mycosphaerella graminicola (Adhikari et al. 2007). However, Vargas et al. (2012) reported that mRNAs of several defense-related genes, reactive oxygen species, and antimicrobial compounds in maize started to accumulate early in the infection process of Colletotrichum graminicola and continued to accumulate during the biotrophic stage. Further studies are needed to completely characterize the gene (such as full length identification, influence of biotic stress on gene expression etc.). Studies, in this direction are in progress.

\section{Acknowledgements}

This study was supported by the INSPIRE Fellowship, Department of Science and Technology, Government of India, New Delhi to the first author.

\section{References}

Adhikari, T.B., Balaji, B., Breeden, J., Goodwin, S.B. 2007. Resistance of wheat to Mycosphaerella graminicola involves early and late peaks of gene expression. Physiol. Plant Pathol. 71:55-68.

Al-Taweel, K., Fernando, W.G.D. 2011. Differential gene expression is a promising tool for understanding of host-pathogen interactions. Amer. J. Plant Sci. Biotech. 5:1-10.

Altschul, S.F., Madden, T.L., Schaffer, A.A., Zhang, J.H., Zhang, Z., Miller, W., Lipman, D.J. 1997. Gapped BLAST and PSI-BLAST: a new generation of protein database search programs. Nucleic Acids Res. 25:3389-3402.

Bachem, C.W.B., van der Hoefen, R.S., de Bruijn, S.M., Vreugdenhil, D., Zabeau, M., Visser, R.G.F. 1996. Visualization of differential gene expression using a novel method of RNA fingerprinting based on AFLP: Analysis of gene expression during potato tuber development. Plant J. 9:745-753.

Benitez, Y., Botella, M.A., Trapero, A., Alsalimiya, M., Caballero, J.L., Dorado, G., Munoz-Blanco, J. 2005. Molecular analysis of the interaction between Olea europaea and the biotrophic fungus, Spilocaea oleagina. Mol. Plant. Pathol. 6:425-438.

Birch, P.R.J., Kamoun, S. 2000. Studying interaction transcriptomes: coordinated analyses of gene expression during plant-microorganism interactions. In: Wood, R. (ed.), New Technologies for Life Sciences: A Trends Guide. Elsevier Science. New York, USA. pp. 77-82.

Boller, T., Felix, G. 2009. A renaissance of elicitors: perception of microbe-associated molecular patterns and danger signals by pattern-recognition receptors. Annu. Rev. Plant Biol. 60:379-406.

Brenner, S., Johnson, M., Bridgham, J., Golda, G., Lloyd, D.H., Johnson, D., Luo, S., McCurdy, S., Foy. M., Ewan, M., Roth, R., George, D., Eletr, S., Albrecht, G., Vermaas, E., Williams, S.R., Moon, K., Burcham, T., Pallas, M., DuBridge, R.B., Kirchner, J., Fearon, K., Mao, J., Corcoran, K. 2000. Gene expression analysis by massively parallel signature sequencing (MPSS) on microbead arrays. Nat. Biotechnol. 18:630634. 
Caldo, R.A., Nettleton, D., Peng, J., Wise, R.P. 2006. Stage-specific suppression of basal defense discriminates barley plants containing fast and delayed-acting mla powdery mildew resistance alleles. Mol. Plant Microbe Interact. 19:939-947.

Clarke, J.D., Zhu, T. 2006. Microarray analysis of the transcriptome as a stepping stone towards understanding biological systems: practical considerations and perspectives. Plant J. 45:630-650.

Collinge, M., Boller, T. 2001. Differential induction of two potato genes, Stprx2 and StNAC in response to infection by Phytophthora infestans and wounding. Plant Mol. Biol. 46:521-529.

Dixon, R.A. 1986. The phytoalexin response: Elicitation, signalling and control of host gene expression. Biol. Rev. 61:239-291.

Dodds, P.N., Rathjen, J.P. 2010. Plant immunity: towards an integrated view of plant-pathogen interactions. Nature Reviews 11:539-548.

Doehlemann, G., Wahl, R., Horst, R.J., Voll, L.M., Usadel, B., Poree, F., Stitt, M., Pons-Kuhnemann, J., Sonnewald, U., Kahmann, R. 2008. Reprogramming a maize plant: transcriptional and metabolic changes induced by the fungal biotroph, Ustilago maydis. Plant J. 56:181-195.

Donson, J., Fang, Y., Espiritu-Santo, G., Xing, W., Salazar, A., Miyamoto, S., Armendarez, V., Volkmuth, W. 2002. Comprehensive gene expression analysis by transcript profiling. Plant Mol. Biol. 48:75-97.

George, M.L., Regalado, E., Warburton, M., Vasal, S., Hoisington, D. 2004. Genetic diversity of maize inbred lines in relation to downy mildew. Euphytica 135:145-155.

Gomez-Gomez, L., Boller, T. 2000. FLS2: An LRR receptor-like kinase involved in the perception of the bacterial elicitor flagellin in Arabidopsis. Mol. Cell. 5:1003-1011.

Gururani, M.A., Venkatesh, J., Upadhyaya, C.P., Nookaraju, A., Pandey, S.K., Park, S.W. 2012. Plant disease resistance genes: Current status and future directions. Physiol. Mol. Plant Pathol. 78:51-65.

Hardie, D.G. 1999. Plant protein serine/threonine kinases: Classification and function. Annu. Rev. Plant Physiol. Plant Mol. Biol. 50:97-131.

Jagoueix-Eveillard, S., Tarendeau, F., Guolter, K., Danet, J.L., Bové, J.M., Garnier, M. 2001. Catharanthus roseus genes regulated differentially by mollicute infections. Mol. Plant-Microbe Interact. 14:225-233.

Jones, J.D., Dangl, J.L. 2006. The plant immune system. Nature 444:323-329.

Kim, S., Park, J., Park, S.Y., Mitchell, T.K., Lee, Y.H. 2010. Identification and analysis of in planta expressed genes of Magnaporthe oryzae. BMC Genomics 11:104.

Liang, P. 2002. A decade of differential display. BioTechniques 33:338-346.

Liang, P., Pardee, A.B. 1992. Differential display of eukaryotic messenger RNA by means of the polymerase chain reaction. Science 257:967-971.

Linthorst, H.J.M. 1991. Pathogenesis-related proteins of plants. Crit. Rev. Plant Sci. 10:123-150.

Lovejot, K., Senthil, N., Bharthi, M., Govindraju, P., Rabindran, R., Nagarajan, P. 2015. Transcriptomic analysis by cDNA RAPD profiling of differentially expressed genes upon infection of Mungbean Yellow Mosaic Virus. Indian Res. J. Genet. Biotech. 7:1-10.

Marcel, S., Sawers, R., Oakeley, E., Angliker, H., Paszkowski, U. 2010. Tissue adapted invasion strategies of the rice blast fungus, Magnaporthe oryzae. Plant Cell 22:3177-3187.

Martin, G.B., Brommonschenkel, S.H., Chunwongse, J., Frary, A., Ganal, M.W., Spivey, R., Wu, T., Earle, E.D., Tanksley, S.D. 1993. Map-based cloning of a protein kinase gene conferring disease resistance in tomato. Science 262:1432-1436.

Mittler, R., Lam, E. 1995. Identification, characterization and purification of a tobacco endonuclease activity induced upon hypersensitive response cell death. Plant Cell 7:1951-1962.

Mosquera, G., Giraldo, M.C., Khang, C.H., Coughlan, S., Valent, B. 2009. Interaction transcriptome analysis identifies Magnaporthe oryzae BAS1-4, as biotrophy-associated secreted proteins in rice blast disease. Plant Cell 21:1273-1290.

Munoz, C.I., Bailey, A.M. 1998. A cutinase-encoding gene from Phytophthora capsici isolated by differentialdisplay RT-PCR. Curr. Genet. 33:225-230.

Narayana, Y.D., Mughogho, L.K., Bandyopadhyay, R. 1995. Evaluation of greenhouse inoculation techniques to screen sorghum for resistance to downy mildew. Euphytica 86:49-53. 
Narsai, R., Wang, C., Chen, J., Wu, J., Shou, H., Whelan, J. 2013. Antagonistic, overlapping and distinct responses to biotic stress in rice (Oryza sativa) and interactions with abiotic stress. BMC Genomics 14:93.

Osbourn, A.E. 1996. Preformed antimicrobial compounds and plant defense against fungal attack. Plant Cell 8:1821-1831.

Rashid, Z., Zaidi, P.H., Vinavan, M.T., Sharma, S.S., Setty, T.A.S. 2013. Downy mildew resistance in maize (Zea mays L.) across Peronosclerospora species in low land tropical Asia. Crop Prot. 43:183-191.

Sambrook, J.E., Fritsch, F., Maniatis, T. 2001. Molecular Cloning: A Laboratory Manual, $3^{\text {rd }}$ ed. Cold Spring Harbor Laboratory Press. Cold Spring Harbor, NY, USA:

Seehaus, K., Tenhaken, R. 1998. Cloning of genes by mRNA differential display induced during the hypersensitive reaction of soybean after inoculation with Pseudomonas syringae pv. glycinea. Plant Mol. Biol. 38:1225-1234.

Shimkets, R.A., Lowe, D.G., Tai, J.T., Sehl, P., Jin, H., Yang, R., Predki, P.F., Rothberg, B.E., Murtha, M.T., Roth, M.E., Shenoy, S.G., Windemuth, A., Simpson, J.W., Simons, J.F., Daley, M.P., Gold, S.A., McKenna, M.P., Hillan, K., Went, G.T., Rothberg, J.M. 1999. Gene expression analysis by transcript profiling coupled to a gene database query. Nat. Biotechnol. 17:798-803.

Showalter, A.M. 1993. Structure and function of plant cell wall proteins. Plant Cell 5:9-23.

Sireesha, Y., Meena, S., Velazhahan, R. 2015. Metabolic response of downy mildew resistant and susceptible maize genotypes to Peronosclerospora sorghi. J. Pure Appl. Microbiol. 9:1355-1362.

Song, W.Y., Wang, G.L., Chen, L.L., Kim, H.S., Pi, L.Y., Holsten, T., Gardner, J., Wang, B., Zhai, W.X., Zhu, L.H., Fauquet, C., Ronald, P. 1995. A receptor kinase-like protein encoded by the rice disease resistance gene, Xa21. Science 270:1804-1806.

Torregrosa, C., Cluzet, S., Fournier, J., Huguet, T., Gamas, P., Prosperi, J.M., Esquerre Tugaye, M.T., Dumas, B., Jacquet, C. 2004. Cytological, genetic and molecular analysis to characterize compatible and incompatible interactions between Medicago truncatula and Colletotrichum trifolii. Mol. Plant Microbe Interact. 17:909-920.

Tripathi, A., Aggarwal, R., Yadav, A. 2013. Differential expression analysis of defense-related genes responsive to Tilletia indica infection in wheat. Turk. J. Biol. 37:606-613.

Vargas, W.A., Martin, J.M., Rech, G.E., Rivera, L.P., Benito, E.P., Diaz-Minguez, Thon, M.R., Sukno, S.A. 2012. Plant defense mechanisms are activated during biotrophic and necrotrophic development of Colletotrichum graminicola in maize. Plant Physiol. 158:1342-1358.

Velculescu, V.E., Zhang, L., Vogelstein, B., Kinzler, K.W. 1995. Serial analysis of gene expression. Science 270:484-487.

Walker, J.C. 1994. Structure and function of the receptor-like protein kinases of higher plants. Plant Mol. Biol. 26:1599-1609.

Wang, Z., Gerstein, M., Snyder, M. 2009. RNA-Seq: a revolutionary tool for transcriptomics. Nat. Rev. Genet. 10:57-63.

Wise, R.P., Moscou, M.J., Bogdanove, A.J., Whitham, S.A. 2007. Transcript profiling in host-pathogen interactions. Annu. Rev. Phytopathol. 45:329-369.

Yang, K., Rong, W., Qi, L., Li, J., Wei, X., Zhang, Z. 2013. Isolation and characterization of a novel wheat cysteine-rich receptor-like kinase gene induced by Rhizoctonia cerealis. Sci. Rep. 3:3021.

Yang, Y., Shah, J., Klessig, D.F. 1997. Signal perception and transduction in plant defense responses. Gene Dev. 11:1621-1639.

Yen, T.T.O., Prasanna, B.M., Setty, T.A.S., Rathore, R.S. 2004. Genetic variability for resistance to sorghum downy mildew (Peronosclerospora sorghi) and Rajasthan downy mildew (P. heteropogoni) in the tropical/ sub-tropical Asian maize germplasm. Euphytica 138:23-31.

Yoshimura, S., Yamanochi, U., Katayose, Y., Toki, S., Wang, Z., Kono, I., Kurata, N., Yano, M., Iwata, N., Sasaki, T. 1998. Expression of Xal, a bacterial blight-resistance gene in rice, is induced by bacterial inoculation. Proc. Natl Acad. Sci. 95:1663-1668. 


\section{Electronic Supplementary Material (ESM)}

Electronic Supplementary Material (ESM) associated with this article can be found at the website of CRC at http://www.akademiai.com/content/120427/

Electronic Supplementary Table S1. Oligonucleotide primers used in DDRT-PCR analysis

Electronic Supplementary Figure S1. Amplification profile of differentially expressed transcripts obtained with primers OPC-09 (A), OPD-03 (B) and OPD-06 (C) in susceptible (CM 500) or resistant (MAI 756) maize genotypes inoculated with $P$. sorghi. Numbers indicate days after inoculation. Arrow shows a differentially expressed cDNA. Letters (b, g, i) indicate band IDs as per Table 1 